\title{
Influence of pedo-climatic conditions on the quality of Iris
}

\section{pallida rhizomes}

\author{
B. Pezzarossa ${ }^{1}$, E. Borghesi ${ }^{1}$, R. Pini ${ }^{1}$, F. Bretzel ${ }^{1}$, R. Maggini ${ }^{2}$ and F. Malorgio ${ }^{2}$ \\ ${ }^{1}$ Research Institute on Terrestrial Ecosystems (IRET), CNR, Pisa, Italy \\ ${ }^{2}$ Department of Agriculture, Food and Environment, University of Pisa, Pisa, Italy
}

\section{Summary}

The rhizomes of Iris pallida, known as orris root, are an important source of essential oils for the perfume industry and of the powder used for making gins and cordials. Rhizomes contain irones, ketone compounds formed from iridals during post-harvest ageing. Iris pallida is cultivated in Europe, mainly in Italy and France, and in Morocco and India. The Italian product is highly sought after due to its qualitative characteristics. Little is known about the influence of pedo-climatic conditions on the quality of the cultivated rhizomes. Our investigation was carried out in the Iris pallida cultivation area of Tuscany (Italy) and intended to assess the possible relationship between the chemical profile of iridals, the climate, and soil properties. Seven farms were selected based on the significance of the cultivated surface, i.e., minimum area of $0.3 \mathrm{ha}$, and the proximity to the weather stations. A climate survey was conducted. Soil was analysed for the main physico-chemical characteristics and rhizomes for the content of iridals.

Our results showed that despite the different physico-chemical soil properties and different rainfall regimes that characterize the cultivation areas, the iridals concentrations in rhizomes did not differ among farms. This supports the hypothesis that Iris pallida behaves like a hardy species by adapting well to different cultivation environments, especially to both non-calcareous and calcareous soils. The observed adaptability of this species to different environments might contribute to the spread of this crop even in marginal soils. This could generate more income for farmers. The cultivation of terrace soil could improve soil and water conservation, as well as decrease soil erosion. Further studies are needed to understand the dynamics of the accumulation of iridals in the rhizomes, and to identify the factors that influence the iridal transformation in irones.

Keywords

iridals, iripallidal, irones, orris root, soil characteristics, Tuscany (Italy)

\section{Introduction}

Iris is the largest genus of the Iridaceae family, a diverse group of perennial evergreen or deciduous herbs found worldwide mostly in temperate regions. The rhizomes of many Iris species have pharmacological activities and have been used in traditional and modern medicine. In food products, it is used as a flavoring agent in syrups, and it is added

\section{Significance of this study}

What is already known on this subject?

- The ketone compounds (irones) contained in rhizomes of Iris pallida and formed by the chemical oxidative degradation of iridals, which are initially present in the rhizomes, seem to be affected by several factors such as the potassium fertilization, the age of the plant, the post-harvest conditions of the rhizomes, and the different extraction techniques. Little is known about the influence of pedo-climatic conditions and cultural practices on the quality of the cultivated rhizomes.

What are the new findings?

- Despite the different physico-chemical soil properties and different rainfall regimes that characterize the cultivation areas under study, no significant differences in the iridals concentrations were observed. Soil and climate conditions might not have markedly influenced the accumulation of iridals, and support the hypothesis that Iris pallida behaves like a hardy species by adapting well to different environments, especially to both non-calcareous and calcareous soils.

What is the expected impact on horticulture?

- The observed adaptability of Iris pallida to the different pedo-climatic conditions might contribute to the spread of this crop even in marginal soils. This could generate more income for farmers, who would otherwise not be able to cultivate less fertile soils. The cultivation of terraced soil could further improve soil and water conservation, as well as decrease soil erosion.

to Middle-eastern dishes as spice (Crișan and Cantor, 2016).

The rhizomes of Iris pallida Lam. and Iris germanica L., known as orris, are an important source of valuable aromatic raw material (Roger et al., 2012). Rhizomes contain irones, which are ketone compounds that are attractive due to their violet-like and powdery fragrance (Kassak, 2012; Masson et al., 2014; Kukula-Koch et al., 2015; Mykhailenko, 2018). After harvesting and sun-drying, irones are formed slowly during the post-harvest ageing of rhizomes, which lasts about 3-5 years, by the chemical oxidative degradation of triterpenoids called iridals which are initially present in the rhizomes (Firmin et al., 1998). The irone precursors (iridals) have been identified mainly as iripallidal and iriflorental in Iris pallida (Bicchi et al., 1993), and $\alpha$-irigermanal in Iris germanica (Marner et al., 1982). 
Depending on the distillation process used, different orris fractions are obtained: concrete oil or butter, obtained by steam distillation, and used as base note in fragrances by perfumers; absolute, obtained by alcoholic extraction of the concrete; resin, obtained from alcohol extraction; and root extract (Burdock, 1994). Orris root powder is used as a fixative in perfumes to enhance other aromas, and as a stabilizer in cosmetics, but also for making gins and cordials (Tonutti and Diddle, 2010), and in the baking, printing and textile industries.

Iris is cultivated in Europe, above all in Italy and France, Morocco, and India, and is one of the most representative plants of the traditional Mediterranean landscape (Pignatti et al., 2000; Roger et al., 2012). The Iris species cultivated in Italy for medicinal and aromatic purposes are Iris pallida, very valuable and grown especially in the Chianti area, and Iris germanica, less valuable and present in the Verona region. Iris pallida is mostly cultivated in Tuscany as a secondary crop in family-owned farms where the main cultivations are olive trees or grapes (Belletti et al., 2013). The plants are usually cultivated where other crops would fail and where the steep slopes limit the use of machinery. Iris pallida is a rustic, vigorous, and hardy species, capable of successfully adapting to difficult cultivation environments, especially in terms of physical and chemical soil characteristics (Pignatti et al., 2000). Plants are frequently attacked by slugs, snails and porcupines. Diseases affecting Iris include bacterial soft rot and leaf spot.

Iris is a long-day plant and its cultivation process is summarized as follows: i) planting of cuttings, i.e., part of rhizomes with roots and leaves stored at harvest, from mid-July to early September); ii) mechanical weed control in April and September; iii) harvest of rhizomes in July and August, after three years from planting.

After harvest, rhizomes are processed, and their leaves and roots removed. Rhizomes are then washed and left in the sun to dry out. After 4-6 months of storage the product is ready for sale on the international market.

The Tuscan product is highly sought after, particularly due to the qualitative characteristics of the crops (Figure 1).

Little is known about the influence of pedo-climatic conditions and cultural practices on the quality of the cultivated rhizomes. Many factors have been suggested as affecting the scent of the final product: the soil and climate of the production area, the age of the plant, the post-harvest conditions of the rhizomes, and the different extraction techniques (Landi, 1994). Fertilizers do not seem to influence the production of rhizomes and the iridal content, except for potassium (Landi, 1994).

The present study is a preliminary investigation aimed at identifying the pedo-climatic factors that influence the quality of the rhizomes of Iris pallida Lam. and to assess the possible relationship between the chemical profile of iridals, the climate, and soil properties. The cultivated area was studied following a multidisciplinary approach dictated by the plurality of factors that make up a homogeneous agro-ecosystem and that contribute to the qualitative production characteristics.
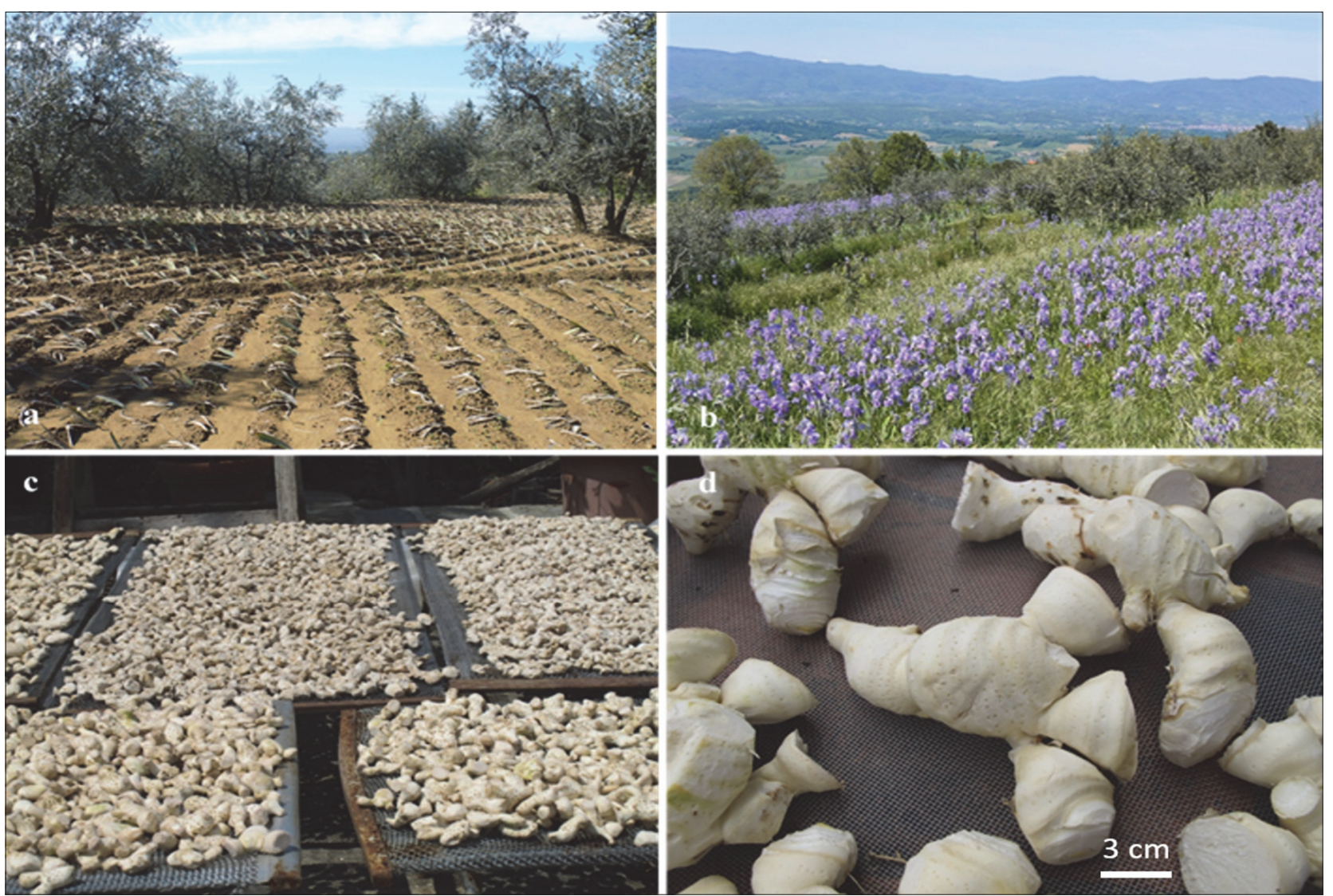

FIGURE 1. Cultivation of iris in Tuscany (Italy): Rooted cuttings planting (a); Iris in full bloom (b); Sun drying of decorticated iris rhizomes (c); Decorticated iris rhizomes (d). 


\section{Materials and methods}

\section{Study area}

This study was carried out in the Iris pallida cultivation area of Tuscany (Italy) in 2014. Based on the information provided by the farmers' association, most of the farms that cultivate Iris are spread out over an area stretching between $43^{\circ} 29^{\prime}$ and $43^{\circ} 40^{\prime} \mathrm{N}$, and between $11^{\circ} 18^{\prime}$ and $11^{\circ} 38^{\prime} \mathrm{E}$, which is crossed by the Arno river.

Seven farms were selected based on the significance of the cultivated surface, i.e., minimum area of 0.3 ha, and the proximity to the weather stations installed by the Regional Hydrological Service of Tuscany, in order to review the climatic history of the areas under study. Three of these farms were located in Chianti (hereafter called C1, C2 and C3, respectively), and four in Pratomagno (hereafter called P1, P2, P3, and P4, respectively). Iris was cultivated as the main crop on P1, and as a secondary crop on the other farms.

\section{Climate survey}

Air temperature and precipitation data were collected from the weather stations of the Regional Hydrological Service (http://www.sir.toscana.it/) located near the investigated farms. Processing was carried out on data over the last decade. The maximum, minimum and average temperature values, and the coefficient of variation were recorded in the decade 2005-2014.

The monthly trend of average, maximum and minimum temperatures in 2012 was investigated, because of its minimum deviation from the historical trend values.

To evaluate the effect of temperature on plant growth and development, the number of heat units (GDD) received by the iris crop during the cultivation period (from February to August, 2012) was estimated. Temperature data were used to determine the Growing Degree Days (GDDs), according to the following equation, as described by Villa-Nova et al. (1972):

$$
\mathrm{GDD}=\sum_{i=1}^{K}\left(\frac{\text { Tmax }+ \text { Tmin }}{2}\right)-\text { Tbase }
$$

where: Tmax is the daily maximum temperature; Tmin is the daily minimum temperature; Tbase is the base temperature below which the growth and development of a plant are significantly inhibited; and $\mathrm{K}$ is the number of days in the period.

The GDDs were determined considering the Tbase of $6^{\circ} \mathrm{C}$, as indicated by Khodorova et al. (2013).

\section{Sampling and analysis of soil}

On each farm a 1,000 $\mathrm{m}^{2}$ plot with 3-year-old plants of Iris pallida was selected. Soil samples were collected by composite sampling. At harvest time (July), four samples of about $1 \mathrm{~kg}$ at a depth of $0-25 \mathrm{~cm}$ were taken from each plot. The samples were subsequently mixed thoroughly and four subsamples were used for physico-chemical analyses.

Air dried soil samples were treated by wet sieving in order to separate skeleton particles $(>2 \mathrm{~mm})$. Soil analyses were performed on the $0-2 \mathrm{~mm}$ fraction. Soil texture (sand, silt, and clay) was determined according to Gee and Bauer (1986), $\mathrm{pH}$ was measured at a soil:water ratio of 1:2.5 with a glass electrode (Thomas, 1996), and cation exchange capacity (CEC) was determined using barium chloride $(\mathrm{pH}=8.1)$ (Sumner et al., 1996). The organic and inorganic carbon and nitrogen contents were determined using a Leco CHN Analyzer. The content of available potassium $(\mathrm{K})$, calcium $(\mathrm{Ca})$ and magnesium (Mg) was determined following Helmke and Sparks (1996).

The total metal content was determined by atomic absorption spectrometry after digestion of the soil with HNO $(65 \% \mathrm{v} / \mathrm{v})$ and $\mathrm{H}_{2} \mathrm{O}(30 \% \mathrm{v} / \mathrm{v})$ in a PTEF-TMF (polytetrafluoroethylene-tetrafluoromethoxyl) pressure digestion vessel in a microwave oven (FKVETHOS900) using the USEPA method 3051-A (U.S. Environmental Protection Agency, 1995).

\section{Analysis of rhizomes}

Five 3-year-old Iris pallida plants were harvested in each farm. The pooled rhizomes from the five plants were cleaned, peeled, cut into small pieces and stored at $-80^{\circ} \mathrm{C}$. For each pooled sample, four replicates $(1 \mathrm{~g})$ were extracted twice with acetone (Gozu et al., 1993) and analysed within two weeks from sampling. Each replicate was ground in a mortar with $5 \mathrm{~mL}$ of acetone. The extract was stirred for 4 hours in an ice bath, kept overnight at $-20^{\circ} \mathrm{C}$, and centrifuged. After separation of the supernatant, the pellet was extracted again with $5 \mathrm{~mL}$ fresh acetone.

The HPLC apparatus (Jasco, Tokyo, Japan) was equipped with a low pressure PU-2089 quaternary pump and a UV2077 multi-channel spectrophotometric detector. The analyses were performed at room temperature with a C18 250/4.6 Nucleodur ${ }^{\circledR}$ 100-5 column (Macherey-Nagel, Düren, Germany) at a $1 \mathrm{~mL} \mathrm{~min}^{-1}$ flow rate, using methanol and water as the elution solvents.

Due to the unavailability of reference standards, the compounds associated with the two main chromatographic peaks were isolated individually from the extracts by semi-preparative chromatography, using a C18 10/250 VarioPrep Nucleodur Isis 5- $\mu$ m column (Macherey-Nagel, Düren, Germany). The two fractions containing the compounds of interest were collected separately, and each solid compound obtained after eluent evaporation was weighed and dissolved in a small known volume of acetone. The solutions used for calibration were obtained by appropriate dilution, and the concentrations in the samples were expressed on a fresh weight (FW) basis.

For peak identification, liquid chromatography-mass spectrometry (LC-MS) or tandem mass spectrometry (LCMS-MS) analyses were carried out by Atmospheric Pressure Chemical Ionization (APCI), using the same column and the same elution gradient used for the HPLC. The apparatus consisted in a PE Sciex API 365 triple quadrupole mass spectrometer (Concord, ON, Canada), equipped with an APCI ion source with a heated nebulizer and coupled to a PE $200 \mathrm{Se}-$ ries HPLC system with a quaternary pump and autosampler.

\section{Statistical analysis}

Data were subjected to one-way analysis of variance (ANOVA). The means were separated using the least significant difference (LSD) test for $P=0.05$. Pearson correlation coefficients $(r)$ were calculated for selected physico-chemical properties of the soil and iridal content of rhizomes.

The soil properties were analysed by Principal Components Analysis (PCA). All variables were mean-centred and weighed by their standard deviation to give them equal variance. The results of the PCA analysis were used to establish farm groups with different profiles for the soil physico-chemical parameters, and to verify whether there was a possible correlation among the rhizome iridal content and the principal components. All statistics were conducted using specific software (Statgraphics 5.1, Statistical Graphics Corp., USA). 


\section{Results and discussion}

\section{Climatic data}

1. Temperature. Only a small variability in the data was detected among the individual weather stations. The minimum temperature recorded at the Greve and Lamole stations and the average temperature recorded at the Lamole station showed slightly higher coefficients of variation.

The average temperature trend during 2012 was the same for all the weather stations, with slight but not significant differences shown by the Lamole and Casarota stations (data not shown).

The average heat accumulation is referred to as the Growing Degree Days (GDD), which could be useful to describe the phenology of the various species, and to compare one region to another, or one season to another. The degree-day method is based on the assumption that plants require a certain amount of energy represented by the sum of the thermal degrees necessary to complete a given phenological stage or the total cycle (Gadioli et al., 2000).

The GDDs of Iris during the cultivation period in 2012 were calculated on the basis of the daily values registered in each weather station. There were about 2,000 GDDs in all the weather stations, except for Lamole which recorded higher values (2,262 GDD), and for Pratomagno which recorded slightly lower values (1,760 GDD).

It is likely that climatic conditions, environmental factors, including irradiance, temperature and water availability, and the accumulation of GDDs lead to changes in the growth and metabolism of a given species (Rodrigues et al., 2014). GDDs describe the growth and metabolism of plants more accurately than chronological measurement systems and facilitate estimations of the duration of plant developmental stages and the determination of probable harvest dates. The growing degree days of several species are known, e.g., Rosa spp. takes about 700-900 GDDs from pruning to flower (Pasian and Liet, 1994), and calla lily (Zantedeschia aethiopica (L.) Spreng.) requires 1,000 GDDs in the initial growth phase and 3,500 GDDs to facilitate an increased production of flower stalks (Rodrigues et al., 2014). Results of the present investigation suggest that in the area and in the period under study, there were more than 1,700 Iris pallida GGDs from the vegetative growth resumption to the harvest. Different temperature conditions could lead to a reduction or extension of the growth cycle of Iris. In the P4 farm (Pratomagno area) an earlier rhizome maturation could be expected if compared to the other investigated farms.

2. Precipitation. The average cumulative annual precipitation in the decade 2005-2014 showed a higher amount of rain in the Lamole and Pian di Sco areas (about 1,000 mm). The farms investigated can be divided approximately into three groups: C1-C3-P2, characterized by heavy rainfall (960-1,020 mm per year); P3-P4, characterized by average precipitation ( $900-920 \mathrm{~mm}$ per year); C2-P1 characterized by moderate rainfall ( $860 \mathrm{~mm}$ per year) (Supplemental Information - Figure S1).

\section{Soil characterization}

The main physical and chemical properties of the investigated soils are reported in Table 1.

According to the United States Department of Agriculture and the National Cooperative Soil Survey classification (Soil Survey Staff, 2014), the soils of the investigated farms were classified as follows: sandy loam in C1, C2, P3, and P4; loamy sand in P2; loam in C3; sandy-clay loam in P1. The skeleton was lower in P2, P3 and P4 and showed the highest value in $\mathrm{C} 2$ and $\mathrm{C} 3$.

The soil pH was neutral (6.7-6.8) in C1, P3 and P4, slightly alcaline (7.9-8.0) in C2, C3 and P1 and slightly acid (6.3) in P2 (Table 1).

The total calcium content, calculated as the calcium carbonate content, was consistently higher in C2 and C3, compared to the other investigated farms which showed values ranging from 1.3 to $7.7 \mathrm{mg} \mathrm{kg}^{-1}$.

The soil cationic exchange capacity was generally high in all farms except for P2.

The soil nitrogen content was low $(0.1 \%)$, except for C2 and P4 farms where the $\mathrm{N}$ content was $0.2 \%$. The organic carbon content (Table 1) showed very low values in all the soils investigated, similar to those of cultivated Tuscan soils, usually in the range 1-2\% (Fantappiè et al., 2010; Sapkota et al., 2012).

The good supply of available $\mathrm{K}$ in all the analyzed soils

TABLE 1. Main soil physical and chemical properties of the investigated farms.

\begin{tabular}{|c|c|c|c|c|c|c|c|c|}
\hline \multirow{2}{*}{\multicolumn{2}{|c|}{ Soil properties }} & \multicolumn{7}{|c|}{ Farm } \\
\hline & & C1 & $\mathrm{C} 2$ & C3 & P1 & P2 & P3 & P4 \\
\hline $\mathrm{pH}$ & & $6.7 \pm 0.2 b$ & $8.0 \pm 0.1 \mathrm{a}$ & $7.9 \pm 0.1 \mathrm{a}$ & $7.9 \pm 0.1 \mathrm{a}$ & $6.3 \pm 0.1 b$ & $6.8 \pm 0.1 b$ & $6.7 \pm 0 . b$ \\
\hline Skeleton & $\%$ & $19.8 \pm 4.6 b$ & $38.8 \pm 11.4 \mathrm{a}$ & $20.3 \pm 2.7 \mathrm{ab}$ & $18.5 \pm 4.8 \mathrm{bc}$ & $3.5 \pm 1.6 \mathrm{~d}$ & $5.6 \pm 2.1 \mathrm{~d}$ & $7.0 \pm 1.8 \mathrm{~cd}$ \\
\hline Clay & $\%$ & $9.0 \pm 0.8 \mathrm{c}$ & $14.6 \pm 3.3 b$ & $22.1 \pm 3.3 \mathrm{a}$ & $22.0 \pm 0.4 \mathrm{a}$ & $6.6 \pm 0.9 c$ & $10.1 \pm 0.8 b c$ & $10.1 \pm 1.6 \mathrm{c}$ \\
\hline Silt & $\%$ & $21.8 \pm 0.6 b$ & $26.9 \pm 1.9 a$ & $30.5 \pm 1.3 \mathrm{a}$ & $19.0 \pm 1.4 b$ & $14.5 \pm 0.5 \mathrm{c}$ & $18.6 \pm 1.4 b$ & $22.4 \pm 2 b$ \\
\hline Sand & $\%$ & $69.3 \pm 1.3 b$ & $58.6 \pm 5.1 \mathrm{c}$ & $47.4 \pm 2.1 \mathrm{~d}$ & $59.0 \pm 1.9 c$ & $78.8 \pm 1.2 \mathrm{a}$ & $71.3 \pm 2.1 b$ & $67.5 \pm 3.6 b$ \\
\hline CEC* & $\mathrm{cmol}(+) \mathrm{kg}^{-1}$ & $23.1 \pm 0.8 b c$ & $27.2 \pm 1 . a$ & $21.5 \pm 0.6 \mathrm{c}$ & $29.4 \pm 0.4 a$ & $17.5 \pm 2.4 \mathrm{~d}$ & $25.6 \pm 1.3 \mathrm{ab}$ & $27.2 \pm 0.9 a$ \\
\hline $\mathrm{CaCO}_{3}$ & $\mathrm{~g} \mathrm{~kg}^{-1}$ & $2.1 \pm 0.2 c$ & $62 \pm 14.3 b$ & $378 \pm 18.5 \mathrm{a}$ & $7.7 \pm 3.5 c$ & $1.3 \pm 0.1 \mathrm{c}$ & $1.3 \pm 0.1 \mathrm{c}$ & $5.3 \pm 3.8 \mathrm{c}$ \\
\hline C org & $\%$ & $0.9 \pm 0 \mathrm{~cd}$ & $1.4 \pm 0.1 b$ & $1.3 \pm 0.1 \mathrm{bc}$ & $0.7 \pm 0.1 d$ & $0.9 \pm 0.1 \mathrm{~d}$ & $0.8 \pm 0.1 d$ & $1.8 \pm 0.3 \mathrm{a}$ \\
\hline C inorg & $\%$ & $0.0 \mathrm{c}$ & $0.7 \pm 0.2 b$ & $4.5 \pm 0.2 \mathrm{a}$ & $0.1 \pm 0.0 \mathrm{c}$ & $0.0 \mathrm{c}$ & $0.0 \mathrm{c}$ & $0.1 \pm 0.0 \mathrm{c}$ \\
\hline $\mathrm{N}$ & $\%$ & $0.11 \pm 0.01 b$ & $0.16 \pm 0.02 \mathrm{ab}$ & $0.13 \pm 0.01 b$ & $0.07 \pm 0.01 \mathrm{c}$ & $0.06 \pm 0.01 \mathrm{c}$ & $0.06 \pm 0.01 \mathrm{c}$ & $0.19 \pm 0.01 \mathrm{a}$ \\
\hline Available K & $\mathrm{g} \mathrm{kg}^{-1}$ & $0.08 \pm 0.01 c$ & $0.10 \pm 0.01 \mathrm{c}$ & $0.19 \pm 0.01 b$ & $0.11 \pm 0.01 \mathrm{c}$ & $0.07 \pm 0.01 \mathrm{c}$ & $0.28 \pm 0.06 \mathrm{a}$ & $0.14 \pm 0.01 b c$ \\
\hline Available $\mathrm{Ca}$ & $\mathrm{g} \mathrm{kg}^{-1}$ & $9.08 \pm 0.6 \mathrm{~cd}$ & $30.6 \pm 2.2 \mathrm{a}$ & $26.1 \pm 0.02 b$ & $15.04 \pm 2.03 c$ & $5.36 \pm 0.27 d$ & $9.2 \pm 0.27 \mathrm{~cd}$ & $10.7 \pm 4.56 \mathrm{~cd}$ \\
\hline Available Mg & $\mathrm{g} \mathrm{kg}^{-1}$ & $0.24 \pm 0.04 \mathrm{a}$ & $0.08 \pm 0.01 \mathrm{c}$ & $0.07 \pm 0.002 c$ & $0.14 \pm 0.03 b c$ & $0.23 \pm 0.02 a$ & $0.21 \pm 0.03 a$ & $0.19 \pm 0.02 a b$ \\
\hline
\end{tabular}

${ }^{*}$ CEC: cation exchange capacity.

Data are means of 4 replicates $\pm S E$. Values followed by different letters in each row are statistically different for $P \leq 0.05$. 


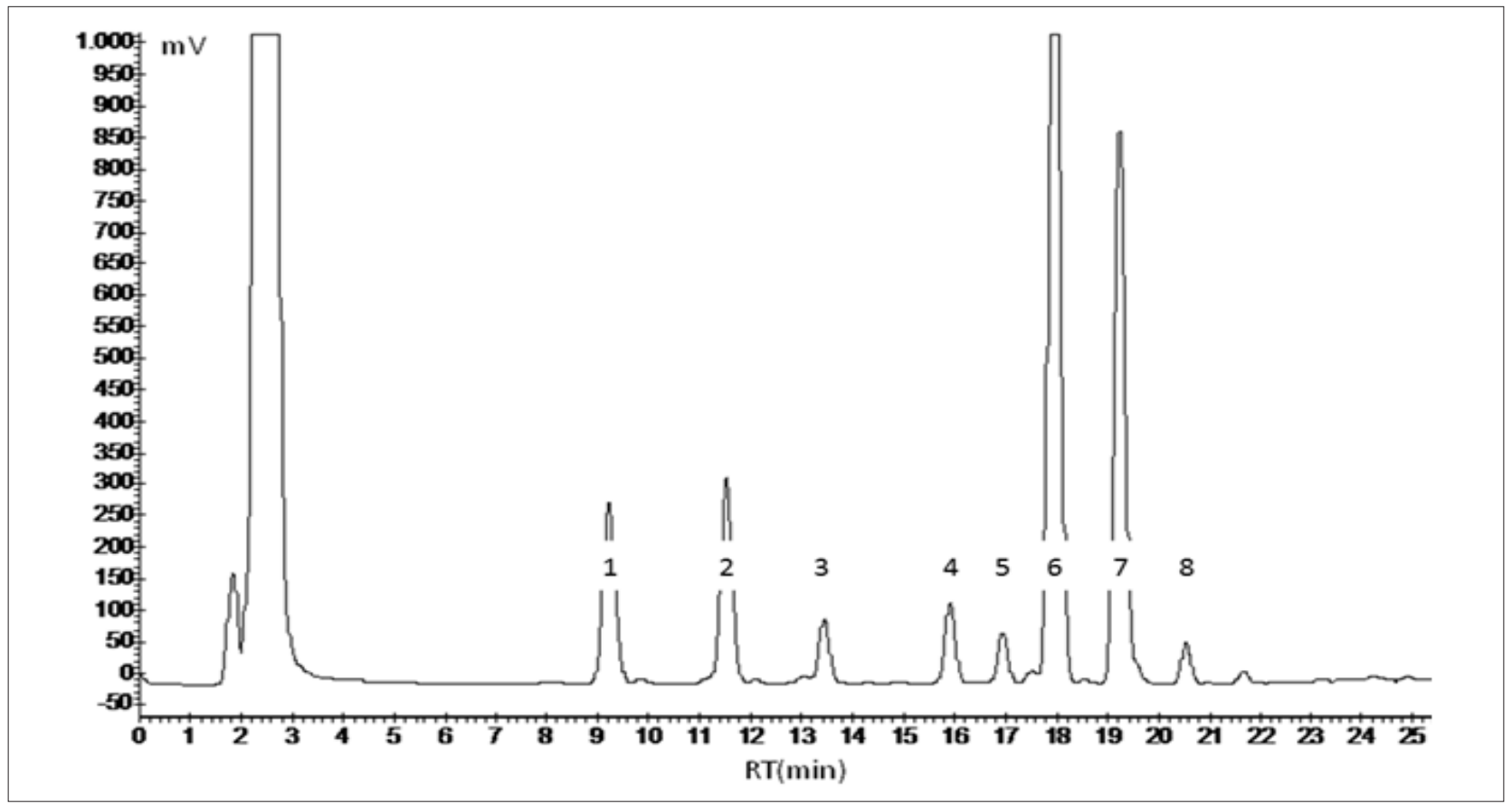

FIGURE 2. Chromatogram of an acetonic extract of Iris pallida rhizome tissue collected in Tuscany (Italy) after three years of cultivation and storage at $-80^{\circ} \mathrm{C}$. See text for details on chromatographic conditions.

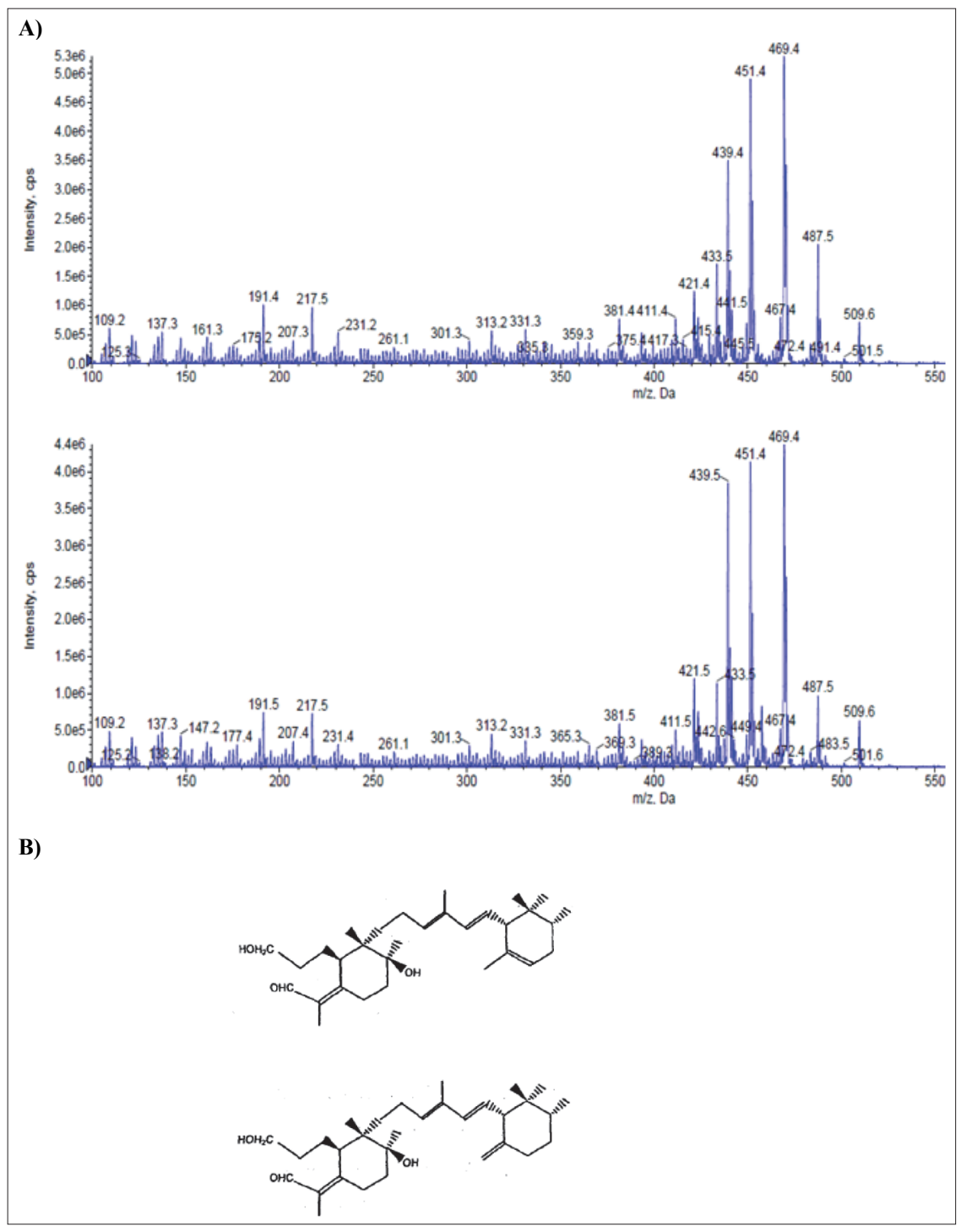

FiguRE 3. A) Mass spectra associated to peak 6 (top) and peak 7 (bottom) in Iris pallida rhizome extracts. See Figure 2 for peak numbering. B) Molecular structures of iripallidal (top) and iriflorental (bottom). 


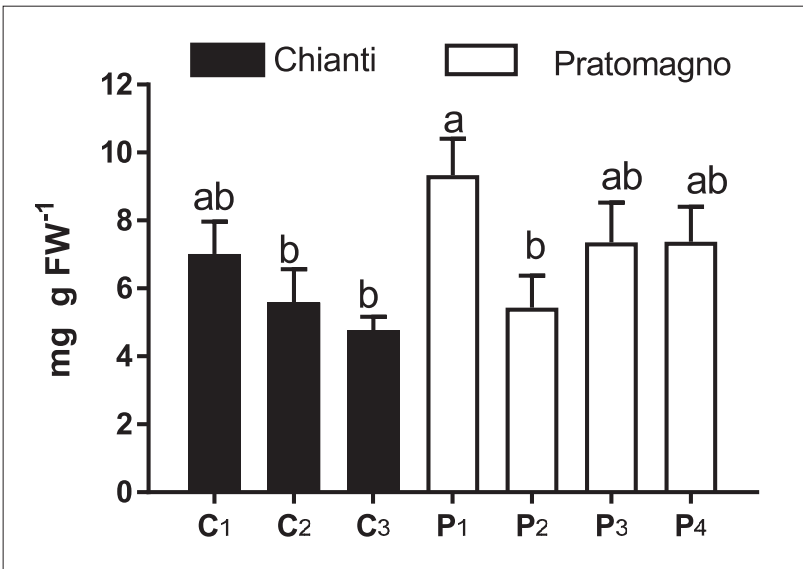

FIGURE 4. Total concentration of iridals (expressed as $\mathrm{mg} \mathrm{g}^{-1}$ on a fresh weight basis) in Iris pallida rhizome tissues from different farms in Tuscany (Italy). The rhizomes were collected after three years of cultivation and stored at $-80^{\circ} \mathrm{C}$. Mean values $( \pm$ SD) of four replicates. Distinct lower-case letters indicate different values at $5 \%$ level of significance.

satisfied the nutritional needs of Iris pallida which has a high potassium requirement. The low content of total nitrogen did not affect the quality of the rhizome production, as already demonstrated by Landi (1994).

\section{Iridals determination}

Irrespectively of the plant cultivation area, all the acetonic extracts of the rhizome tissue showed the chromatographic profile reported in Figure 2. Under the experimental conditions adopted, the HPLC chromatogram of the rhizomes extracts consisted of eight peaks in the range of 5-25 minutes. Two main peaks ( 6 and 7 ) were observed at retention times within 17.5 and 20 minutes.

Among the eight compounds in the chromatograms, only compounds 6 and 7 were identified as iridals. Their complete mass spectra are shown in Figure 3A, along with the molecular structures of iripallidal and iriflorental (Figure 3B).

According to the literature, iripallidal and iriflorental are the most abundant iridals contained in the rhizome tissues of I. pallida (Landi, 1994; Masson et al., 2014). Since pure reference standards are not commercially available for these compounds, no direct comparison with our samples was possible in terms of either retention times or UV absorption. Thus, preliminary LC-MS and LC-MS-MS analyses were carried out for peak identification. The molecular fragmentation patterns observed for the two main peaks ( 6 and 7) are consistent with the structures of both iripallidal and iriflorental (Figure 3) and with published mass spectrometry data (Masson et al., 2014).

In the mass spectra associated with peaks 6 and 7 (Figure 3A), the ions at m/z 487 (molecular ion) and 509 (sodium adduct) are consistent with the molecular mass of both iriflorental and iripallidal (Figure 3B). In addition, the two intense signals at $\mathrm{m} / \mathrm{z} 469$ and 451 could be ascribed to the loss of one or two hydroxyl groups as $\mathrm{H}_{2} \mathrm{O}$. In the experimental conditions applied, the fragmentation patterns of the two compounds were very similar (Figure 3A) and did not enable peak 6 or 7 to be identified as iripallidal or iriflorental. However, the two molecules shown in Figure 3B are isomers which differ only in terms of the position of a double bond, which could explain the difficulty in distinguishing between the two iridals by mass spectrometry.

A loss of one or more water molecules was observed in the fragmentation patterns of all the other compounds in the chromatograms, which generally showed intense signals that differed by 18 mass units. All the structures showed marked similarities with those of the iridals associated with peaks 6 and 7. For example, strong signals at $\mathrm{m} / \mathrm{z} 469$ and 451 and a signal at $\mathrm{m} / \mathrm{z} 433$ were also observed in the fragmentation patterns of peaks 2 and 3, while similar fragments shifted by two mass units were found for peak 4 (m/z 453 and 435) and peak 8 (m/z 471, 453 and 435). These could indicate a structural difference which may concern either a double bond or a ring. Similarly, a difference of two mass units was observed by comparing the fragmentation patterns of peak $5(\mathrm{~m} / \mathrm{z} 455$ and 437) and peak $1(\mathrm{~m} / \mathrm{z} 457$ and 439). The mass spectrum of peak $5(\mathrm{~m} / \mathrm{z} 473,455,437)$ could be indicative of a demethylated iridal.

A precise structure elucidation would require further LCMS and LC-MS-MS analyses using experimental conditions that favour molecular fragmentation, as well as the use of other spectrometric identification techniques such as $\mathrm{Nu}$ clear Magnetic Resonance (Roger et al., 2012; Potterat et al.,

TABLE 2. Pearson's correlation coefficients for the traits ${ }^{1}$ studied $(n=28)$.

\begin{tabular}{|c|c|c|c|c|c|c|c|c|c|c|c|c|c|}
\hline & $\mathrm{Ca}$ & $\mathrm{CaCO}_{3}$ & CEC & C-inor & Clay & C-org & Iridals & $K$ & $\mathrm{Mg}$ & $\mathrm{N}$ & $\mathrm{pH}$ & Sand & Silt \\
\hline $\mathrm{CaCO}_{3}$ & 0.28 & & & & & & & & & & & & \\
\hline CEC & 0.22 & 0.19 & & & & & & & & & & & \\
\hline C-inor & $0.60^{\star *}$ & 0.22 & -0.23 & & & & & & & & & & \\
\hline Clay & $0.63^{* *}$ & -0.02 & 0.37 & 0.57 & & & & & & & & & \\
\hline C-org & 0.27 & $1.00^{* *}$ & 0.21 & 0.21 & -0.01 & & & & & & & & \\
\hline Iridals & -0.18 & -0.22 & $0.48^{\star *}$ & -0.38 & 0.11 & -0.22 & & & & & & & \\
\hline K & 0.08 & -0.03 & 0.19 & 0.22 & 0.17 & -0.04 & 0.04 & & & & & & \\
\hline Mg & $-0.84^{* *}$ & -0.19 & -0.25 & -0.58 & $-0.65^{\star *}$ & -0.19 & 0.02 & -0.02 & & & & & \\
\hline$N$ & 0.37 & $0.87^{\star *}$ & 0.26 & 0.20 & 0.05 & $0.86^{* *}$ & -0.13 & -0.09 & -0.28 & & & & \\
\hline $\mathrm{pH}$ & $0.87^{* *}$ & 0.03 & 0.36 & 0.49 & $0.80^{* *}$ & 0.03 & 0.03 & 0.12 & $-0.84^{\star *}$ & 0.08 & & & \\
\hline Sand & $-0.79^{* *}$ & -0.25 & -0.32 & -0.71 & $-0.91^{* *}$ & -0.25 & 0.06 & -0.18 & $0.7^{* *}$ & -0.33 & $-0.81^{* *}$ & & \\
\hline Silt & $0.80^{* *}$ & $0.50^{* *}$ & 0.19 & 0.70 & $0.60^{* *}$ & $0.50^{* *}$ & -0.25 & 0.16 & $-0.64^{* *}$ & $0.57^{* *}$ & $0.63^{* *}$ & $-0.88^{* *}$ & \\
\hline Skeleton & $0.65^{\star *}$ & 0.05 & 0.11 & 0.23 & 0.19 & 0.04 & -0.10 & -0.13 & $-0.57^{\star *}$ & 0.12 & $0.64^{* *}$ & -0.30 & 0.36 \\
\hline
\end{tabular}

${ }^{1} \mathrm{Ca}$ : available soil calcium content; $\mathrm{CaCO}_{3}$ : calcium carbonate; $\mathrm{CEC}$ : cation exchange capacity; $\mathrm{C}$ inor: soil inorganic carbon content; Clay: soil clay content; C org: soil organic carbon content; Iridals: rhizome iridal content; $\mathrm{K}$ : available soil potassium content; Mg: available soil magnesium content; $\mathrm{N}$ : available soil nitrogen content; Skeleton: soil fraction $>2 \mathrm{~mm}$. 


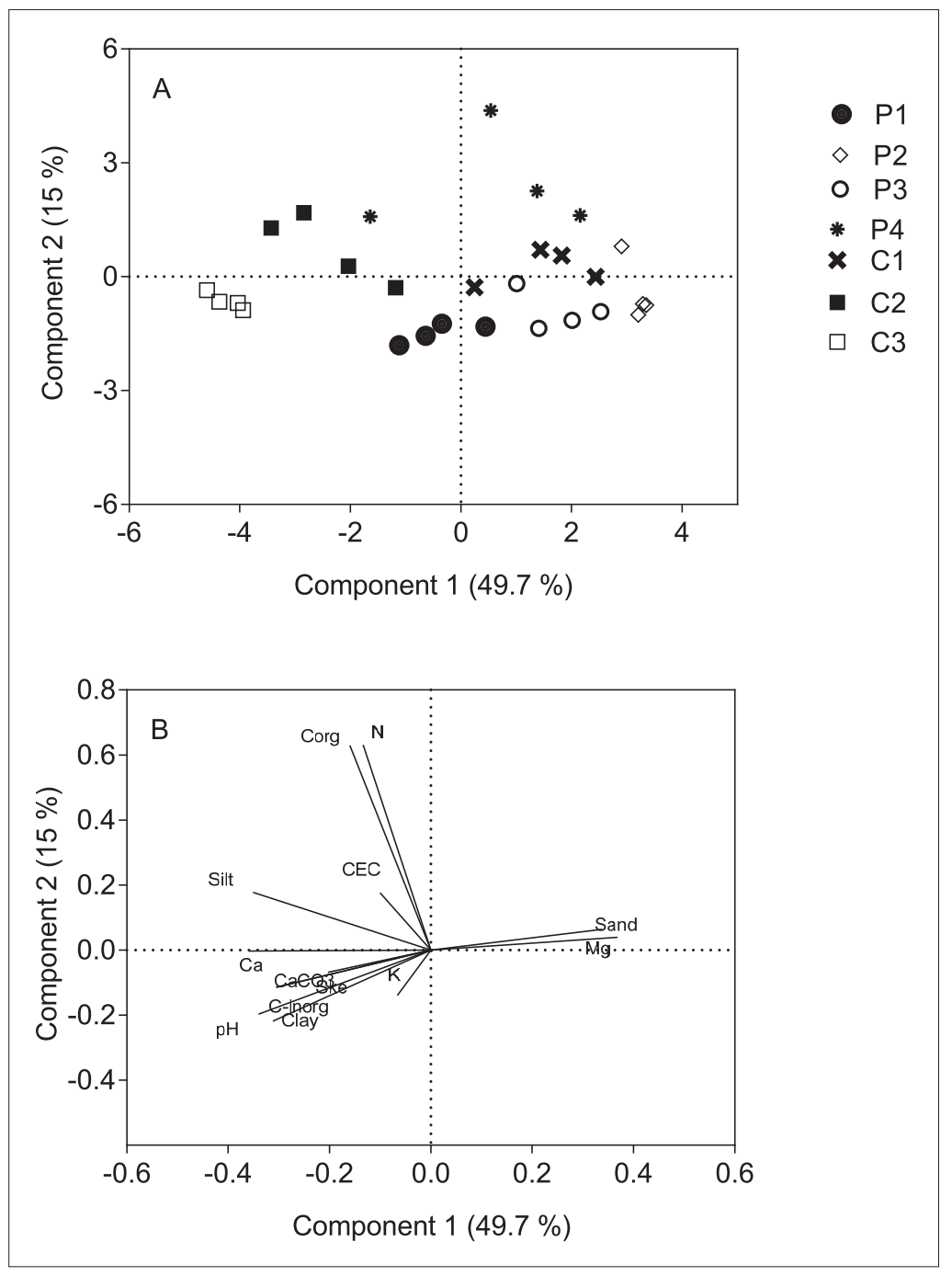

FIGURE 5. Data score (A) and variability loading (B) obtained with PCA. In (B) similarity among the investigated farms based on thirteen traits are represented on the two first components (first component, x-axis; second component, $y$-axis) of the principal component analysis.

In Figure 5B: Ca: available soil calcium content; $\mathrm{CaCO}_{3}$ : calcium carbonate; $\mathrm{CEC}$ : cationic exchange capacity; $\mathrm{C}$-inor: soil inorganic carbon content; Clay: soil clay content; Corg: soil organic carbon content; Iridals: rhizome iridal content; K: available soil potassium content; Mg: available soil magnesium content; $\mathrm{N}$ : available soil nitrogen content; Skeleton: soil fraction $>2 \mathrm{~mm}$ in diameter.

TABLE 3. Correlation coefficients for each trait for the four Principal Components, Eigen value, and relative and cumulative proportion of the total variance explained by these components.

\begin{tabular}{lcccc}
\hline Traits & PC1 & PC2 & PC3 & PC4 \\
\hline $\mathrm{pH}$ & -0.340 & -0.197 & 0.281 & -0.057 \\
Skeleton & -0.203 & -0.068 & 0.297 & -0.510 \\
Clay & -0.312 & -0.218 & 0.110 & 0.257 \\
Silt & -0.351 & 0.178 & -0.112 & 0.049 \\
Sand & 0.369 & 0.039 & -0.008 & -0.180 \\
CEC $^{*}$ & -0.100 & 0.176 & 0.579 & 0.429 \\
$\mathrm{~K}$ & -0.066 & -0.140 & -0.119 & 0.629 \\
$\mathrm{C}$-org & -0.133 & 0.631 & -0.111 & 0.026 \\
$\mathrm{~N}$ & -0.160 & 0.630 & -0.035 & -0.017 \\
$\mathrm{C}$-inor & -0.305 & -0.114 & -0.453 & -0.018 \\
Ca $^{-0.359}$ & -0.003 & 0.120 & -0.168 \\
Mg & -0.338 & -0.146 & 0.163 \\
CaCO $_{3}$ & -0.305 & -0.114 & -0.452 & -0.018 \\
\hline Eigen valu* & 6.5 & 2.18 & 1.81 & 1.48 \\
Variance (\%) & 49.7 & 15.0 & 12.7 & 10.1 \\
Cumulative variance (\%) $^{* *}$ & 49.7 & 64.6 & 77.3 & 87.5 \\
\hline
\end{tabular}

* CEC: Cation Exchange Capacity. ${ }^{* *}$ Eigen value measures the amount of variation in the total sample accounted for by each factor. Values in bold show statistically significant correlation. 
2014). In any case, some information was obtained from the LC-MS analyses, which is in agreement with previously published results. Several iridal-type compounds, whose molecules are only slightly different from one another, have been found in Iris rhizomes (Bicchi and Rubiolo, 1993; Bonfils and Sauvaire, 1996; Kukula-Koch et al., 2015). In addition, since the iridals undergo post-harvest oxidative degradation leading to the formation of the scented molecules of irones (Bicchi et al., 1993), iridal-type molecules may also be involved in the intermediate steps of this complex process. However, while the biosynthetic pathways have been investigated for several iridals (Marner, 1997), much less is known concerning the time evolution of the chemical profile determined by the transformations which occur during the post-harvest storage period.

The concentration of iridal 6 (2.747-5.311 $\left.\mathrm{mg} \mathrm{g}^{-1} \mathrm{FW}\right)$ was generally higher than iridal 7 (1.864-4.025 mg g-1 $\mathrm{FW}$ ). The total concentrations of the two iridals in the samples are reported in Figure 4. Only the rhizomes collected in P1 showed significantly higher iridal levels than those from the two farms in Chianti $(\mathrm{C} 2, \mathrm{C} 3)$ and the one in Pratomagno (P2). No other differences were found in the total concentrations of iridals, which averaged $6.74 \pm 2.23 \mathrm{mg} \mathrm{g}^{-1} \mathrm{FW}$.

\section{Principal component analysis}

The pairwise correlation coefficients among traits were statistically significant $(P<0.05)$ for nine out of thirteen traits studied. The highest positive correlation was between the calcium carbonate and organic carbon contents $(r=0.99)$, clay and $\mathrm{pH}(r=0.80)$, and calcium and silt ( $r=0.79)$ (Table 2$)$.

For the traits analyzed, the first four principal components were associated with Eigen values $>1$, and accounted for more than $87 \%$ of the cumulative variance. The first and second components of the PCA accounted, respectively, for $49.7 \%$ and $15 \%$ of the total variation of the traits investigated (Table 3).

The first component, which explained $49.7 \%$ of the variance, was positively correlated with sand and Mg (correlation values 0.37 and 0.34 , respectively) and negatively with silt, clay, $\mathrm{pH}$, and calcium (correlation values between -0.31 and -0.36$)$. The second component ( $15 \%$ of variability) presented a high positive correlation with C-org and N (correlation values 0.63 ).

The projection of the individual farms in the PCA plot shows that the farms are widely spread over the graph area (Figure 5A). C3 showed the lowest values both for the first and the second components. P2 and P3 showed positive values for the first component and negative for the second components. C1 and P4 showed positive values both for the first and the second components.

No correlation was found between the iridal content in the rhizomes and the first and the second principal components (data not shown).

The PC1 and PC2 score plot separates and categorizes farms into four groups (quadrants) (Figure 5B). The upper left quadrant of the negative side of PC1 included C2 farm characterized by high CEC, N and C-organic content. A second group clustered on the positive side of PC1 included C1 and C4 farm that showed high level of sand and Mg.

In conclusion, despite the different physico-chemical soil properties and different rainfall regimes that characterize the cultivation areas, the iridals concentrations in rizomes did not differ among farms. These findings suggest that soil and climate conditions might not have markedly influenced the accumulation of iridals, and support the hypothesis that Iris pallida behaves like a hardy species by adapting well to different cultivation environments, especially to both non-calcareous and calcareous soils. The observed adaptability of Iris pallida to the different pedo-climatic conditions might contribute to the spread of this crop even in marginal soils. This could generate more income for farmers, who would otherwise not be able to cultivate less fertile soils. In general, the cultivation of terrace soil could improve soil and water conservation, as well as decrease soil erosion.

\section{Acknowledgments}

This work was supported by Tuscany Region (Italy). The authors would like to thank Irene Rosellini and Manuele Scatena for their technical assistance in the soil analyses.

\section{References}

Belletti, G., Fani, E., Marescotti, A., and Scaramuzzi, S. (2013). The role of traditional products in the valorisation of marginal rural areas: the case of Iris pallida. Span. J. Rural Dev. 4, 11-22. https:// doi.org/10.5261/2013.GEN4.02.

Bicchi, C., Rubiolo, P., and Rovida, C. (1993). Analysis of constituents of Iris rhizomes. Part II. Simultaneous SFE of irones and iridals from Iris pallida L. rhizomes. Flavour Fragr. J. 8, 261-267. https://doi. org/10.1002/ffj.2730080505.

Bonfils, J.P., and Sauvaire, Y. (1996). Localization of iridals in Iris germanica rhizomes. Phytochem. 5, 1281-1285. https://doi. org/10.1016/0031-9422(95)00758-X.

Burdock, G.A. (1994). Fenaroli's Handbook of Flavor Ingredients, $3^{\text {rd }}$ edn., Vol. 2. (Boca Raton, FL: CRC Press).

Crişan, I., and Cantor, M. (2016). New perspectives on medicinal properties and uses of Iris sp. Hop and Med. Plants 1-2, 24-36.

Fantappiè, M., L'Abate, G., and Costantini, E. (2010). Factors influencing soil organic carbon stock variations in Italy during the last three decades. In Land Degradation and Desertification: Assessment, Mitigation and Remediation, P. Zdruli, M. Pagliai, S. Kapur, and A. Faz Cano (eds.) (Dordrecht, The Netherlands: Springer), https://doi.org/10.1007/978-90-481-8657-0_34.

Firmin, L., Courtois, D., Pétiard, V., Ehret, C., and Lerch, K. (1998). Evaluation of the natural variability in irone content and selection of Iris sp. for perfume production. HortScience 33, 1046-1047. https:// doi.org/10.21273/HORTSCI.33.6.1046.

Gadioli, J.L., Dourado-Neto, D., García, A.G., and Basanta, M.V. (2000). Air temperature, maize yield and phenological characterization associated to heat units. Sci. Agric. 57, 377-383. https://doi. org/10.1590/S0103-90162000000300001.

Gee, G.W., and Bauder, J.W. (1986). Particle-size analysis. In Methods of Soil Analysis, Part 1, Physical and Mineralogical Methods. Agronomy Monograph No. 9 (2 ${ }^{\text {nd }}$ edn.), A. Klute (ed.) (Madison, USA: American Society of Agronomy/Soil Science Society of America), p. 383-411.

Gozu, Y., Yokoama, M., Nakamura, M., Mamba, R., Yomogida, K., Yanagi, M., and Nakamura, S. (1993). In vitro propagation of Iris pallida. Plant Cell Rep. 13, 12-16. https://doi.org/10.1007/BF00232307.

Helmke, P., and Sparks, D.L. (1996). Lithium, sodium, potassium, rubidium, and cesium. In Methods of Soil Analysis, Part 3, Chemical Methods, D.L. Sparks (ed.) (Madison, WI: SSSA Book Ser. 5), p. 551574. https://doi.org/10.2136/sssabookser5.3.c19.

Kassak, P. (2012). Screening of the presence of Irone (C14H22-0) in the rootstocks of the chosen Iris species. ARSA 3-7, 1487-1499.

Khodorova, N.V., and Boitel-Conti, M. (2013). The role of temperature 
in the growth and flowering of geophytes. Plants 2, 699-711. https:// doi.org/10.3390/plants2040699.

Kukula-Koch, W., Sieniawska, E., Widelski, J., Urjin, O., Głowniak, P., and Skalicka-Woźniak, K. (2015). Major secondary metabolites of Iris spp. Phytochem. Rev. 14, 51-80. https://doi.org/10.1007/ s11101-013-9333-1.

Landi, R. (1994). Population Performance, Fertilization Effects, and Environmental Factors on Orris Production (Iris pallida Lam.). Int. Conference "Coltivazione e miglioramento di piante officinali", Trento (Italy), June 2-3, p. 47-70.

Marner, F.J. (1997). Iridals and cycloiridals: products of an unusual squalene metabolism in sword lilies (Iridaceae). Curr. Org. Chem. 1, 153-186.

Marner, F.J., Krick, W., Gellrich, B., Jaenicke, L., and Winter, W. (1982). Irigermanal and iridogermanal: two new triterpenoids from rhizomes of Iris germanica. J. Org. Chem. 47, 2531-2538. https://doi. org/10.1021/jo00134a007.

Masson, J., Liberto, E., Brevard, H., Bicchi, C., and Rubiolo, P. (2014). A metabolomic approach to quality determination and authentication of raw plant material in the fragrance field. Iris rhizomes: A case study. J. Chromatogr. 1368, 143-154. https://doi. org/10.1016/j.chroma.2014.09.076.

Mykhailenko, O. (2018). Composition of volatile oil of Iris pallida Lam. from Ukraine. Turk. J. Pharm. Sci. 15(1), 85-90. https://doi. org/10.4274/tjps.07379.

Pasian, C.C., and Lieth, J.H. (1994). Prediction of flowering rose shoot development based on air temperature and thermal units. Sci. Hortic 59, 131-145. https://doi.org/10.1016/0304-4238(94)90080-9.

Pignatti, A., Ubrizsky Savoia, A., and Varoli Piazza, S. (2000). Iris: a significant element of the Mediterranean landscape. Ann. Bot. LVIII, 161-166.

Potterat, O., Herzog, C., Raith, M., Ebrahimi, S.N., and Hamburger, M. (2014). Irigermanone, a noriridal with unprecedented methylketone function, from Iris germanica. Helv. Chim. Acta 97, 32-38. https:// doi.org/10.1002/hlca.201300316.

Rodrigues, M., Duarte De Oliveira Paiva, P., Rodrigues Alves Delfino Barbosa, J.P., and De Oliveira Fontes Mansur, T. (2014). Action of growing degree days on the morphogenesis and physiological responses of calla lily. Acta Physiol. Plant. 36, 1893-1902. https:// doi.org/10.1007/s11738-014-1565-1.

Roger, B., Jeannot, V., Fernandez, X., Cerantola, S., and Chahboun, J. (2012). Characterisation and quantification of flavonoids in Iris germanica L. and Iris pallida Lam. resinoids from Morocco. Phytochem. Anal. 23, 450-455. https://doi.org/10.1002/pca.1379.

Sapkota, T.B., Mazzoncini, M., Bàrberi, P., et al. (2012). Fifteen years of no till increase soil organic matter, microbial biomass and arthropod diversity in cover crop-based arable cropping systems. Agron. Sustain. Dev. 32, 853-863. https://doi.org/10.1007/s13593011-0079-0.

Soil Survey Staff (2014). Soil Survey Field and Laboratory Methods Manual. Soil Survey Investigations Report No. 51, V. 2.0. R. Burt and Soil Survey Staff (eds.) (U.S. Department of Agriculture, Natural Resources Conservation Service)

Sumner, M.E., and Miller, W.P. (1996). Cations exchange capacity and exchange coefficients. In Methods of Soil Analysis, Part 3 - Chemical Methods, Soil Science Society of America Book Series, D.L. Sparks (ed.) (Madison, USA: Soil Science Society of America Inc.), p. 12011230. https://doi.org/10.2136/sssabookser5.3.c40.

Thomas, G.W. (1996). Soil pH and soil acidity. In Methods of Soil Analysis, Part 3 - Chemical Methods, Soil Science Society of America Book Series, D.L. Sparks (ed.) (Madison, USA: Soil Science
Society of America Inc.), p. 475-490. https://doi.org/10.2136/ sssabookser5.3.c16.

Tonutti, I., and Liddle, P. (2010). Aromatic plants in alcoholic beverages. A review. Flavour Fragr. J. 25, 341-350. https://doi. org/10.1002/ffj.2001.

U.S. Environmental Protection Agency (1995). Standard for the use or disposal of sewage sludge. 40 CFR Parts 403 and 503. (Washington, DC: U.S. Gov. Printing Office).

Villa-Nova, N.A., Pedro Junior, M.J., Pereira, A.R., and Ometto, J.C. (1972). Estimation of degree-days above any base temperature, depending on the temperatures: Highs and lows. Caderno de Cencias da Terra $30,1-8$.

Received: Dec. 14, 2018

Accepted: May 20, 2019

Addresses of authors:

Beatrice Pezzarossa ${ }^{1, *}$, Eva Borghesi ${ }^{1}$, Roberto Pini ${ }^{1}$,

Francesca Bretzel $^{1}$, Rita Maggini ${ }^{2}$ and Fernando Malorgio ${ }^{2}$

${ }^{1}$ Research Institute on Terrestrial Ecosystems (IRET), CNR, via Moruzzi 1, 56124 Pisa, Italy

2 Department of Agriculture, Food and Environment, University of Pisa, via del Borghetto 80, 56124 Pisa, Italy

* Corresponding author; E-mail: beatrice.pezzarossa@cnr.it Tel.: +39050 6212488; Fax: +390506212473 


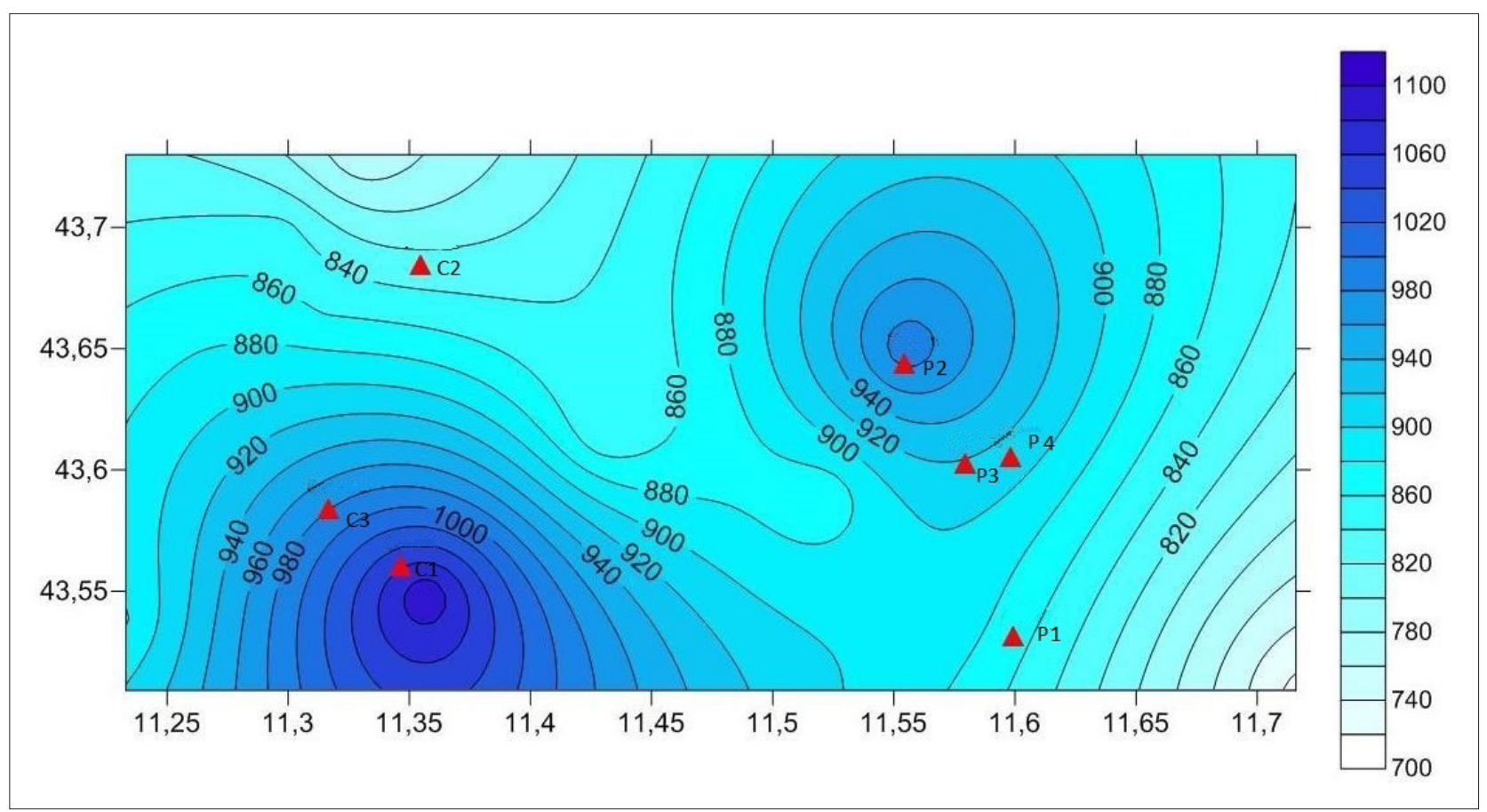

SUPPLEMENTAL INFORMATION - FIGURE S1. Average total annual precipitation in the areas under study. C1, C2 and C3 are the farms located in the Chianti area; P1, P2, P3 and P4 are the farms located in the Pratomagno area. 